\title{
Throwing the Baby Out with the Bathwater Brexit and the Economics of Disengaging from a Free Trade Association
}

\author{
Hallett, Andrew Hughes
}

Document Version

Accepted author manuscript

Published in:

Economic Analysis and Policy

DOI:

10.1016/j.eap.2019.01.004

Publication date:

2019

\section{License \\ CC BY-NC-ND}

Citation for published version (APA):

Hallett, A. H. (2019). Throwing the Baby Out with the Bathwater: Brexit and the Economics of Disengaging from a Free Trade Association. Economic Analysis and Policy, 62, 91-96. https://doi.org/10.1016/j.eap.2019.01.004

Link to publication in CBS Research Portal

\section{General rights}

Copyright and moral rights for the publications made accessible in the public portal are retained by the authors and/or other copyright owners and it is a condition of accessing publications that users recognise and abide by the legal requirements associated with these rights.

Take down policy

If you believe that this document breaches copyright please contact us (research.lib@cbs.dk) providing details, and we will remove access to the work immediately and investigate your claim. 


\title{
Throwing the Baby Out with the Bathwater: Brexit and the Economics of Disengaging from a Free Trade Association
}

\section{Andrew Hughes Hallett}

\author{
Journal article (Accepted manuscript* ${ }^{\star}$
}

\section{Please cite this article as:}

Hallett, A. H. (2019). Throwing the Baby Out with the Bathwater: Brexit and the Economics of Disengaging from a Free Trade Association. Economic Analysis and Policy, 62, 91-96.

https://doi.org/10.1016/j.eap.2019.01.004

DOl: https://doi.org/10.1016/j.eap.2019.01.004

* This version of the article has been accepted for publication and undergone full peer review but has not been through the copyediting, typesetting, pagination and proofreading process, which may lead to differences between this version and the publisher's final version AKA Version of Record.

Uploaded to CBS Research Portal: March २०२1

(C) 2019. This manuscript version is made available under the CC-BY-NC-ND 4.0 license http://creativecommons.org/licenses/by-nc-nd/4.0/ 


\section{Accepted Manuscript}

Throwing the baby out with the bathwater: Brexit and the economics of disengaging from a free trade association

Andrew Hughes Hallett

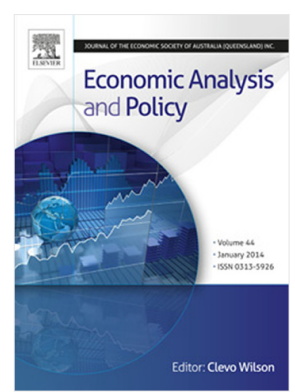

PII: $\quad$ S0313-5926(19)30007-4

DOI: $\quad$ https://doi.org/10.1016/j.eap.2019.01.004

Reference: $\quad$ EAP 270

To appear in: Economic Analysis and Policy

Received date : 10 January 2019

Revised date : 16 January 2019

Accepted date : 16 January 2019

Please cite this article as: A. Hughes Hallett, Throwing the baby out with the bathwater: Brexit and the economics of disengaging from a free trade association. Economic Analysis and Policy (2019), https://doi.org/10.1016/j.eap.2019.01.004

This is a PDF file of an unedited manuscript that has been accepted for publication. As a service to our customers we are providing this early version of the manuscript. The manuscript will undergo copyediting, typesetting, and review of the resulting proof before it is published in its final form. Please note that during the production process errors may be discovered which could affect the content, and all legal disclaimers that apply to the journal pertain. 
Throwing the Baby out with the Bathwater: Brexit and thr $\mathrm{t}_{\mathrm{c}}$ onomics of Disengaging from a Free Trade Association

\author{
Andrew Hughes Hallett \\ Kings College, University of London and Copenhager nusı,... School, Denmark \\ Email: ahughesh@gmu.e 'ı \\ Corresponding autı, $r$ \\ Andrew Hughes Halı"
}

Email: ahughesh@s nu.edu 


\title{
Throwing the Baby out with the Bathwater: Brexit and thr $t$ snomics of Disengaging from a Free Trade Association
}

\begin{abstract}
For nearly six decades or more, international trade policy has been argely ictated by UN (now WTO) supervised rounds of mutual tariff reductions, starting with ${ }^{+} \ldots$ Ke.... dy round in 1961. Initially attention was focused on tariffs as such, but more recently th $2 s^{\prime}$ Jpe has been extended to include services, investment, intellectual property rights, free traci assc-i-ions, and sensitive issues like agricultural goods. As the negotiations became more complicate (and controversial), the speed at which new agreements were agreed slowed down markndly. " he ame popular to argue that bilateral deals, and then agreements that allowed the emerging trade csociations to merge, would be a better way forward - in the hope that mergers between the $a_{1}{ }_{c}$ or associations would lead to free trade worldwide.

Instead, as the academic literature predicted, tr. Ing arrangements have gone in the opposite direction with economies withdrawing from estab. 's. - d associations or violating old ones. This paper, by "reverse engineering" the costs of Brexit as - oxan. le, sets out and examines the costs and different ways a country might disengage itself from a trau चssociation suspected to no longer be advantageous.
\end{abstract}

Keywords: Brexit; Free Trade Agreemer. ‘: Exit ( ssts 


\section{Prologue and a Health Warning}

Brexit, the process by which the UK will voluntarily surrender membership of the ${ }^{-\prime}$ ', is possibly the best example of a policy process that generates more heat than light that we have - oen in decades. Faced with a threat to his government from his own party over the question of $\mathrm{EU}$ rombership, and the fact that the nationalist UKIP party that was running in second place in $\mathrm{m}_{\mathrm{c}}$ " crucial Conservative seats, Prime Minister Cameron called a referendum on the issue in 201\%. Sut nu serious analysis of the economic arguments for or against EU membership, or evaluation of the like / economic outcomes, was offered during the referendum campaign -- or in the following tw- '/eaı . ... len a new trade deal was to be negotiated with the EU. Now that the moment has come for Par' am nt to choose the way forward, the result appears to be political paralysis. The aim of tr:- papor is to try to put the economic implications of Brexit into perspective and, by extension, the pru ass of disengaging from free trade agreement or free trade zones more generally.

A careful reading of the UK government's proposals for a now. : al of association with the EU gives the impression that everything comes down to a choice betw. on two "no deals". There is discussion of the no deal case (leaving without any agreement with $"{ }^{\prime \prime} \cdot{ }^{\prime \prime}$ and of the government's preferred option which is a limited trade deal (but no specific arranger, nts for investment) with two restrictions - that the Irish border may be allowed to settle in the Ir.. : $\neg$; and that the UK shall remain in an EU customs union till 2020 and likely beyond if no othe c-mne ments are settled by December 2020. There are detailed discussions of the remaining budget conı, hutions (separation fees) and the rights of EU citizens

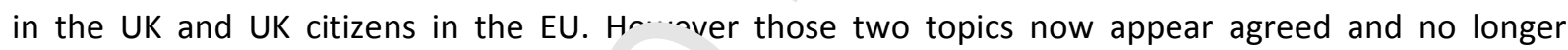
controversial. But there is no material $r, 1$ the tr, de and investment arrangements. In fact, a word search

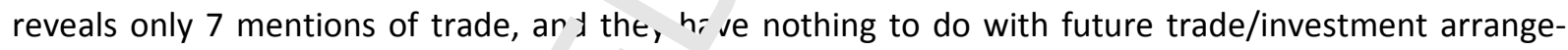
ments. This "deal" therefore descri' es ; crar sition out of the EU, but allows (or is intended to allow) the participants to forget that there - $\mathrm{a}_{4}$-isir $n$ s to be taken within the transition period; and that making, or possibly failing to make, ce win decisions now may rule out many of the preferred options after transition.

Using Brexit as exemplar, $k+r f$.ognising that the results generalise, this paper makes four basic points:

a) Disengaging from a F ee Traqt Association entails significant economic costs and losses in economic performance from red ${ }_{2}$ - ir ns ir trade. These costs will not be spread evenly across the economy; some sectors will be affe ad mu. - than others, as is always the case when the pattern of trade alters. However, these co ts may nly apply in the short to medium term if the economy (and exchange rate in particular), adjuct to . . e competitiveness and develop new markets. This is because trade is a flow, not a stock.

b) Similarly, disc -aar.ng from a Free Trade Association will entail losses in investment: cross-border investmeni эnu $u$. domestic investment that had been necessary to support the trade flows under the agreement. Ir he EU, cross-border investment has assumed special importance because it allows firms 
to exploit the EU's "passporting" arrangements ${ }^{1}$. The point here is investment devel ;ps the economy's productive capacity for the future, and is the gateway for incorporating new prr " 'tivity techniques into the new capacity. Not only does that improve competitiveness; it creates the npportu. ity for future long term growth as the standard growth models show. Hence the loss of invf stm nt is likely to cause far greater long term damage than the immediate losses in trade. This is heca e productive capital (accumulated investment) is a stock, not a flow.

c) Various "compromise" models involving a degree of association or par' al $n$ =1.' '-arship of a free trade zone exist. Mostly they involve administrative changes to how associateu nembers may operate (for example, can the associated member influence the design of the rulf $;$ of th trade zone?); or variations in the trade rules/tariffs applied to associated members (reduced ta. $\mathrm{ffs}$, $\mathrm{rul}: \mathrm{s}$ of origin, some freedom of movement of labour may remain). Each model has different a vantages or disadvantages in terms of costs relative to full membership, in economic performance anc ir che listribution of those costs. The question then is: how do these costs or losses stack up agalı + thic losses of the outside option (no associated membership at all)? Examples of the best knowr romprol lise models are given below.

d) Generally, little detailed analysis has been devoted to ' version to normal WTO trading rules (the default positinn! Ti. is because a full reversion provides no benefits at all; and bilateral deals to improve on that turn - 't to be self-defeating in the sense that they may provide gains to start with, but the trade inte rat ... process will come to a halt when the bloc becomes large enough to act as a trade monor ${ }^{\prime} y$ ar. the dominant players act as a coalition to set tariffs in such a way as to expropriate the gains ot. srated for themselves (Krugman, 1989; Hughes Hallett and Primo Braga, 1994). So unless o. - . - r. minant player in such a regime, there is no real incentive to continue as a member. Arguably, thı is a lesson that the Trump administration has now been condemned to relearn.

The assessments made in this paper are 'nnfin $d$ to membership of the EU's Single Market and regular economic issues that arise naturally rom the urexit decision. They are not intended to address the other important cultural, environmental, $\sim{ }_{\wedge} \mid$ l or security aspects of EU membership that will arise in other contexts. This separation then inplies w. o further points: i) that the lessons to be drawn from this analysis generalise to any case of a 1 . . mber withdrawing from a free trade deal; and ii) the list of special protections for certain sectc s $c$ the EU economy which the EU issued in lieu of a final agreement at the end of 2018 shows that the. $v$ Ill be serious costs to both sides, the EU included, beyond just trade and budgetary losses. Disen s agemen $\mathrm{is} \mathrm{a} \mathrm{two-way} \mathrm{street} \mathrm{in} \mathrm{the} \mathrm{same} \mathrm{way} \mathrm{as} \mathrm{creating} \mathrm{the} \mathrm{free} \mathrm{trade} \mathrm{zone,} \mathrm{if}$ properly conducted, $w$. Ild hav been a Pareto improvement in the first place.

\section{Background}

i) Any discussior of wiru detailed arrangements could or should be made between the UK and EU, or between the ( K's con. tituent regions and either the UK or the EU, short of independence, depends on

\footnotetext{
${ }^{1}$ Passporting , riv . $s$ trum the Single Market ruling that a firm licensed to do business in one member economy is licensed to do business in alı. This allows EU producers to shrink their production to a single EU location (if they wish) and realize the scale economies that resı it. It also allows outsiders to establish a bridgehead position in one EU market and then trade in all of them from there. This is particularly valuable in component or assembly trades, or chain production processes where specialized and high productivity skills are involved.
} 
the trading model that the UK government chooses to adopt with respect to the EU. This will necessarily remain unknown until a now delayed Parliamentary vote is taken in London. But or $r$ 'st experience this vote is not likely to pay much attention to a specific region's - Scotland for example - inte I sts generally (jobs, investment, economic development) or specifically (e.g. natural resources fish ng rights).

ii) A number of models to replace the single market have been in discussior, hut i. ' v all involve trying to achieve the near impossible feat of maintaining free EU market access (:- - lua 1. - for investment and passporting), while limiting the free movement of labour. This involves a Iffic ، - mpromise: especially for the EU where the free movement of labour is a "fundamental freedom -hat, if lost, would sit badly with the continued free movement of capital and investment that $t h: U K v_{i}$ 'ues so highly. This explains why the negotiations have been so drawn out and difficult for both ides, ' nd show so little room for compromise or improvement.

iii) The main contenders are the Norwegian model (stay in the Slis 1 e M rket, contribute to its costs but with no vote on its regulations); the Swiss model (bilateral free $t_{1}$. te deals in selected sectors, allowing the UK the freedom to exploit her comparative advantages,, tay ou with bilateral free trade deals with the EU and other outsiders (not feasible so long as the UK $\mathrm{r}_{\mathrm{m}}$ - to remain in an EU customs union); a rules of origin approach much like NAFTA (cumbersome and ' ..........plement in industries whose inputs are mostly human capital, knowledge based, or skills based - flı. - ncial services for example).

iv) A more explicit compromise would be to stay outs fe che EU but make bilateral free trade deals with the EU and outsiders to replace the Single Mark . vithe it invoking WTO membership; or to stay inside with compromises on certain articles in the Single ' /a «et itself - for example, with quotas to replace the free movement of labour in return for con ' 'SIUis on aspects of EU membership outside the Single Market. This model has been proposed in the unoticial French-German "Continental Partnership" idea [Bruegel (2016a, b)].

v) The "no deal at all" option in which the 'IK I' aves the EU without any agreement ${ }^{2}$. Under this option, the UK would progress to WTO mer ber nip in her own right. However all WTO members have to agree. Currently 7 countries, including the $\therefore$ sa, they oppose UK membership. And even if that obstacle is overcome, the UK would have 'accept the WTO's rules on international and bilateral free trade. The cost of the latter might be reduced $b_{y}$ :nvoking the "most favoured nation" status between UK and EU, but how much benefit that ' oul I bring is not known.

\section{Trade Losses fru,' ear ing the Single Market on the UK side}

Estimates have bef 1 mad? or the impact of Brexit on the UK, but few for Scotland. They produce UK losses of about $1 \%$ 'o $2 \%$ c GDP. These losses are about the same as reversing the gains estimated for membership of "... sirigic market when it was set up. The Cecchini report estimated gains of $5 \%$ in GDP over 5 years ir 1992. i le EU's post-mortem study in 2000 showed GDP gains of $1 \%$ by the time the Euro arrived. Later es : $\mathrm{mat}^{+} \mathrm{s}$ put the figure at $2.15 \%$ of GDP in 2006 , or $2.13 \%$ of GDP in 2014 . For Scotland,

\footnotetext{
${ }^{2}$ This option is - Jw limited by the motion adopted by the UK Parliament in early January 2019, that "no deal at all" cannot be part oi he options offered to Parliament or negotiated with others by the UK government. That obviously restricts the government's freedom of action; but how much impact this would have in practice is not clear. It might be rescinded again in the future, and what do you do if the EU is unable to agree any other option?
} 
the Fraser of Allender Institute has estimated the losses (gains lost) at about $2.8 \%$ of .DP or 80000 jobs. These gains will not have been distributed evenly of course; so the correspondin ' ' sses under Brexit will hit some sectors, such as manufacturing, much harder than others.

For the UK as a whole, the UK Treasury now estimates, rather late in the day, + lat I K GDP will be lower by $3.9 \%$ after 15 years (or $1 / 4 \%$ each year on average) if the government's ; refe. $\neg$ plan is used; but $9.3 \%$ lower ( $0.62 \%$ each year) under no deal at all ${ }^{3}$. This is costly in terms of Insses, riven that it does not account for the investment and productivity increases foregone. Notablv also $\ldots$. - Treasury calculations do not evaluate any of the compromise models either.

The Scottish government figures for Scotland alone suggest losses o $7.4 \%$ c 'ter 12 years, or $0.62 \%$ per year: that is, half way between the government's proposal and the " $r_{1}$ deal $\lambda$ t all" solution. So Scotland would appear to be made worse off than the rest of the UK ( $\mathrm{rU}$, if th - UK were to crash out, although the damage would be less, even on UK Treasury figures, with $y$ of he compromise arrangements currently ruled out (only $5 \%$ under a free trade association $w \cdot h$ tric EU, $1 \%$ in a Norway type deal). Interestingly, the Treasury's argument is that these smaller 'nsses w uld arise because Scotland is partly sheltered by the energy sector. I am not aware that Lond $n$ has " - . act made any plans to devolve oil or gas revenues to provide any such financial sheltering. So it is $\mathrm{n}$. ' clear where this result is coming from. Nevertheless, the argument itself is of interest because 1 -hows how easily the economic outcomes can shift with relatively small changes in the rules gover :- - rade in any new association with the EU.

On these results, by 2030, the loss of productivit" impı vements will explain $60 \%$ of the losses between no deal and continued EU membership; restrict. $x$. igration $26 \%$ of the difference, but new trade barriers and tariffs only $14 \%$-- according to _. loss of investment and productivity gains are the . . ajor factors here and need to be recognised as such. Comparable figures for the UK are not avail-hle.

Finally, restricting net migration to zerc - said $\mathrm{t}$, lower incomes by $5.4 \%$ per capita in the long term.

The reason why the trade impacts a a $\mathrm{nr}:$ larger is that EU tariffs against outsiders average $2 \%-3 \%$. Since the pound has depreciated $15 \%$ sim 1 .he ' ave vote, the cost of UK exports to the EU has fallen. As a result, UK firms are now repo ing inci ased business and the trade deficit is shrinking. However, imports also cost more (aroun $423 \%$ nore so far) - raising the prospect of inflation. Since UK inflation is still within its $2 \%-3 \%$ target . dr. re, this is not a major problem. So, reversing the argument, there has been some downward pres. 're on prices across the EU as a whole, but rather small in its effect.

That said, the evaluatio s sc far report the estimated trade effects only. They do not look at the impact of lost investment ana $\_r$ jeqr ent losses in output and productivity growth. So there is a great deal to add to these estima' $\Rightarrow$ of Brt..It costs. I am less optimistic that we can find a way to offset the combined losses without som ? kind $\mathrm{C}$ single market substitute or compromise, unless you judge the international trade rules of the ' $\mathrm{N}_{1}-$ - $^{-}$- le less restrictive than the EU's free market rules. They are clearly not, unless we can invoke $₫$ most ' ivoured nation status. That part then represents the costs of a clean exit.

\footnotetext{
${ }^{3}$ Figures calculat, 1 as of 2018 [see BBC (2018)]. The Scottish figures that follow are taken from Scottish Government (2018). It may seem odd to in.lude the impacts of Brexit on a specific region. But those costs (or gains) are of importance here because they may persuade that region to reconsider or change their relationship with the national economy in question, especially if that national government has made an unfortunate or damaging choice when disengaging from the EU.
} 


\section{Trade Losses from the UK leaving the Single Market: the EU viev}

Not much can be decided about the future trade regime until the Article 50 procr-c is complete (March 2019 , with a transition period till the end of 2020). How much can be achie' $2 d v$ ithin the remaining two-year time frame is unclear, although it is clear that both sides anticipats mu. ' of the design work will be done in the transition period. This amounts to substantial delay to thn orig.. ᄀ / Brexit timetable.

Why? First, there are strong incentives for the UK to delay negotiating: he ' sngt; the delay, the more the pressures in the EU to compromise build up. One can see that in the G 'man employers' pressure for a single market scheme with work permits; worries that the $\mathrm{Br}$ :xit slo. down puts the stability of Italian banks at risk; the movement to short time working in some $C$-rmar manufacturing plants; and the worries that the Dutch (for example) do not have the perso inel nertise or resources to set up a new customs system for their largest EU trading partner under a ...u dea ' scenario.

Second, the complexity of negotiating replacement arrangemenı. 'where London lacks the necessary expertise and the EU lacks the focus) means that it almos. -erta lly cannot be done in the 2 years allowed. From the UK point of view, better to delay the Arı' $>50$ process till a good part of the design of the agreement that needs to follow has been dor. I I IIs means the UK needs to make known her concerns early in the process, to avoid being presented with . fait accompli. But this has not happened.

Gaming the system in the name of creating a transiz. $\urcorner$ arrangement before a final agreement can be reached, particularly over the question of where ' $\mathrm{N}$ Nor hern Ireland border for trade purposes shall be placed (evident in the disagreements over the corre $t$ interpretation of a previously agreed "backstop" arrangement) has inevitably made this process nore tortuous and the costs involved larger than they need have been.

There are also incentives on the EU si' e to dit te the pressures triggered by Brexit, to make space to create agreement on the future form of th . FI from within, and to allow financial pressures created by the UK's withdrawal to subside. Th . ex $x^{+}$a crsts generated by the Markets in Financial Instruments and Derivatives Initiative-2 is one exa' sple, no e expensive financial services/financing imposed by breaking up the existing financial market ... another. Fragmented liquidity, reduced access to financing, shallower or narrower financial markets and a luss in the ability to pool financing or currency risks, is a third. This imposes costs on everyone , con umers and businesses alike) in the EU or UK, but mostly on the EU side given the depth and greater s, ne of the UK financial markets. For example, the OECD (2018) forecasts Dutch exports could fal' $17 \%$ under a "no deal" Brexit. It is also estimated that the EU as a whole would need additional financin rarg ns of $€ 77 \mathrm{bn}$ just to back the same volume of trades as undertaken today. Disengagement re . Iy is a two way street. It is not surprising that the emergence of the Continental Partnership idea fr $\mathrm{m}$ the $\mathrm{F} \mathrm{J}$ side has indicated a desire for a degree of compromise. But, again, no firm proposals have .ndterlansed - perhaps because the EU is still unclear what it wants to achieve with a new associatic $>$ agree lent, aside from limiting damage to the European integration movement.

\section{Invest, $\mathfrak{t}_{1}, \ldots$ : the Key Element.}

Investment sp nding plays three key roles. First it builds capacity: the ability to produce competitively in the future. The specific quantity spent therefore has a magnified effect on output and employment going forward; and investment lost through Brexit would have a likewise magnified effect in lost output 
and growth. It is hard to put numbers on this since we lack detailed investment dat; , e.g. for Scotland. But we can make estimates: grossing up the figures for public investment in the sar. proportion as the UK shows that new investment runs at around 3.3\% of GDP, a little over half the UK rate , $-\%)$. On these numbers, Scotland can ill afford further losses in investment from Brexit, wheth . $r d_{1}$ e to a slowdown or to lost passporting.

Second, an inability to passport your services/goods into the EU could be vary au naging to investment spending. For obvious reasons we have no data on how much Scottish $\mathrm{i}^{\text {r vest }} \mathrm{k}^{\text {ht }}$ is made to facilitate passporting. But given that $15.3 \%$ of Scottish exports go to the EU (ex-UK), , d 63.8\% to rUK (about 70\% is passported on), the loss of passporting rights directly or via the $U^{\prime}$. woulf mean a loss of more than $16 \%$ in investment. Scottish government figures are more sanguine ( $.7 \%$, or between $6.3 \%$ and $9 \%$ lost over 12 years), the difference being that the loss of passporting ey ... rts u... uugh rUK is not included. ${ }^{4}$

Third, and most important, investment is the way productivity $g^{\text {. " }}$ "th e ters into the economy. In fact, productivity growth is the only source for permanent increases 'n giuwth and employment (Scotland's working population is static or shrinking). Hence lost inves ${ }^{+m}$ ent for Brexit reasons would inflict greater long-run damage to the Scottish economy than the curre. + wt. '. 'Ivestment performance because the capacity to incorporate new productivity gains would shrink.

\section{The link to productivity growth}

As an example: Scotland has labour productivity whic. s $3 \%$ lower than the UK. Yet wages are roughly $6 \%$ lower. This implies that unit labour costs are $3: \cdots$ Ner in Scotland. However, overall production costs per unit are not lower since otherwise the $\mathrm{S}$ - nt+ish 1 . onomy would have grown faster than the rUK. It has not. Growth has been consistently slower $w, 1 / 2 \%-1 \%$ per year than in the rUK. Hence total factor productivity (meaning the way in which the inputs to production are combined) must be lower in Scotland. Scots work harder than their sunter, arts, but to less effect because cheaper labour has been substituted for capital and productivity irı 'ar as. In cases such as these, a sensible policy would be to adopt a two-pronged approach: a gen .ral drive to increase total factor productivity with improved technology, capital deepening, $b$-tte. vor'. practices; plus policies that shift the industry mix towards the high productivity activities nd those with specialised services, skills, and (internal or external) economies of scale. In short. we $\mathrm{nc}_{\mathrm{c}} \mathrm{d}$ more investment in order to exploit trade and Scotland's comparative advantages $\mathrm{mr} ; \mathrm{e} ; \mathrm{r}$ ot less as will happen under any Brexit deal.

\section{Investing in proc'st vity growth}

Digging deeper, Scotlanu unks nighly on R\&D and innovation in the public sector - principally in higher education sector - ' ut dor s less well in business and industry. In fact business R\&D spending runs at half the UK rate. And $m$. 'st of $\mathrm{i}^{1}$ is done by US, Scottish and EU owned firms: very little by UK based firms, a clear "branch c'. .e" proplem. In figures, $53 \%$ is done by US firms, $25 \%$ by Scottish owned firms, $16 \%$ by EU firms and c רly $3 \%$, y UK owned firms. At the same time, $8 \%$ of firms in Scotland by value added are US owned, $31 \%$ a. . . Ion-UK and $61 \%$ are UK owned. Taken together, this means that UK based firms undertake, 'st,$\%$ of the R\&D or innovation spending, per unit value added, of non-UK firms. This

\footnotetext{
${ }^{4}$ The Scottish government figures for investment lost look more likely to be correct: given annual growth rates $1 \%$ slower than in rUK, and an incremental capital-output ratio of 2.5, we should expect an investment loss of $71 \% \%$.
} 
general argument then generalises to the UK as a whole. The simplest strategy, ther, would be to find ways to bring high productivity activities to the local economy by investing in produ $\therefore$ ity growth and by encouraging foreign trade and ownership in order to make UK markets and UK firms mo . contestable (raising competitive pressures). Again the opposite of what Brexit itself would $r$ ing Instead of which, it appears that (by 2030) $60 \%$ of the loss of output/jobs under no deal vs. EU memu ship would be due to an emerging productivity gap; $26 \%$ from the loss of migration, but only $14 \%$, rm trade barriers and market access issues that have taken up so much of the negotiators' time

One additional point: a possible Brexit cost, in economic performance rat. $\checkmark r$ than scientific prowess, would be a loss of research funding and scope (whether from the E J or in . rnally) where the UK does hold a world-wide comparative advantage.

\section{The Costs of a Productivity Slowdown}

There is very little work in the existing literature that wou! ' allow $u$, to estimate the impact of the loss in productivity growth that one might expect from Brexit. This . . . vecause the only estimates that exist (for example from the Treasury, or the Fraser Institute ronnrtl r. :asure the impact of productivity losses arbitrarily imposed from the outside, rather than from 'nsses that we would expect to be induced (endogenously) by the Brexit process itself; and be، 7us ' ${ }^{\circ}$ productivity losses have been imposed on labour productivity when, in view of sections 6 and 7 . Jove, they should have been obtained from the effects on investment and total factor productivit w ve theless, imposing an arbitrary $5 \%$ loss in productivity (the Treasury's assumption), leads to $\sim m$ la .ge negative shock on top of any trade losses. That confirms the general argument in the last two seci: ns.

\section{Conclusion: could the UK fit i. to a r, placement single market arrangement?}

The reality is that, short of crashing out with no deal at all, the UK will have to accept whatever post-EU arrangements are agreed with th 2 Ec -or mission. On the face of it, the Swiss option should probably have found most favour in Lor $\_n$. This would have distinct advantages if the bilateral market access agreements are made in areac where ine UK has comparative advantage: principally financial services, but also in energy services, tect nical services, biotechnology, digital industries, downstream petroleum and chemical products, nrec. nn engineering, pharmaceuticals and medical technology, high quality food, drink and clothir, $A^{\prime}$ this depends on being able to negotiate and agree bilateral deals in the sectors concerned, inclu. "ig c ucially passporting and defining watertight limits to what activities and pass-porting can bf regarred as being legitimately "within sector". It is not clear if this can or would be done satisfactorily, nder $\mathrm{Cl}$ irent arrangements.

A better alterr ative $r$ ight be the Continental Partnership format, as proposed in an unofficial FrenchGerman-Brusse's initia ive, in which the UK's Single Market membership (hence free trade, free market access) is $r$-rorved as it is. But the free movement of labour is suspended, to be controlled instead by a system of $q_{i} \tau^{\prime}$ as or work permits, in return for limited forms of joint regulation - enough to allow passporting $-p$. is a joint say in common single market policies and a degree of joint decision making in some other areas of the EU. That implies a voice, but not necessarily a vote, on setting EU rules. To 
make this a reality, there would have to be contributions to the European budget - at a reduced level compared to regular EU members - and the application of European law to certs. Nefined activities. The details of such a scheme need to be worked out. But it is likely to be superior for the 'K because it retains access to the Single Market, and the freedom to play to the UK's comp r ati : advantages, while respecting the vote to leave the current EU arrangement as it now is. A work pt. nit system for labour migration could be regulated to direct resources and expertise to where the " $"$ has its comparative advantages. Unfortunately the combination of divided politics and a strar sely ' proper analysis of the merits and demerits of the different trading schem ,vailable post-exit have not allowed this to happen or even be considered.

If arrangements of this kind were to be adopted, it would be in th UK's nterest to ensure that the labour movement clause is controlled by a work permit scher e rather than a system of overall UK quotas. This way, the UK could retain an ability to boost certain _ _cors ff the economy, rather than go along with whatever comes out of the general EU agreement.

In contrast to all this, staying outside with across-the-board $1, \circ$ tra' e deals with the EU and others on a bilateral basis would have little value since the economy w. $1 / \mathrm{d}$ remain linked to EU markets and the threat of coalition behaviour by EU firms with little inve 'ment in productivity or comparative advantage as the UK's only real defence.

\section{References}

BBC (2018), quoting the UK Treasurys esun...tes of the costs of Brexit, available at www.bbc.com/news/UK-politics-46366162/ (28 November)

Breugel (2016a), "Europe after Brexi+. a pr posal for a continental partnership", available from http://bruegel.org/2016/08/europe-afte, ''rexi' a-proposal-for-a-continental-partnership/

Breugel (2016b), "Europe after Bre t: a srop ssal for a continental partnership, a reply to five main criticisms", available at http://brı „geı.. "g/ .016/09/the-continental-partnership-proposal-a-reply-tofive-main-criticisms/

Fraser of Allander Institute '८ ‘6), "Long-term Economic Implications of Brexit", Strathclyde Business School, University of Stratt. 'Ivd', Glasgow.

Krugman, Paul (1989) “', Bil „teraısm Necessarily Bad?”, NBER Discussion Paper 2972, National Bureau of Economic Research, : $\rightarrow r$ orid ,e MA

Hughes Hallett, Anr iew, a `d Carlos A Primo Braga (1994), "The New Regionalism and the Threat of Protectionism", in $\mathrm{s}$ 'nan ar $\mathrm{y}$ the International Economies, 8, 388-42

OECD (2018), "، he Pc ential Economic Impact of Brexit on the Netherlands", Economics Department, Working Paper ${ }^{1} 518, F$ aris

Scottish G verı.....t (2018), "Scotland's Place in Europe: People, Jobs and Investment", Scottish Government, . dinburgh, ISBN 978178855467 (15 January) 